\title{
KONDISI PERAIRAN BERDASARKAN BIOINDIKATOR MAKROBENTOS DI SUNGAI SEKETAK TEMBALANG KOTA SEMARANG
}

\author{
Lintang Rina Kawuri, Mustofa Niti Suparjo, dan Suryanti *)
}

Jurusan Perikanan, Fakultas Perikanan dan Ilmu Kelautan, Universitas Diponegoro

Jl. Prof. H. Soedharto, SH, Tembalang Semarang. 50275 Telp/Fax (024) 7474698

\begin{abstract}
Abstrak
Sungai Seketak merupakan sungai yang bagian hulunya berada di wilayah Tembalang yaitu daerah yang sebelumnya berupa daerah terbuka untuk resapan air tetapi kini berubah fungsi menjadi daerah kampus dan permukiman. Perubahan fungsi tersebut diikuti peningkatan kebutuhan masyarakat akan sarana dan prasarana, salah satunya adalah kebutuhan air. Untuk itu, rencana pembuatan waduk Diponegoro dengan membendung Sungai Seketak dianggap sebagai salah satu upaya konservasi air dan pengendalian daya rusak air. Kelompok makrobentos merupakan kelompok hewan yang relatif menetap di dasar perairan dan sering digunakan sebagai petunjuk biologis (indikator) kualitas perairan. Penelitian ini dilakukan pada bulan Juni-Juli 2012 di Sungai Seketak Tembalang yang bertujuan untuk mengetahui kondisi perairan pada stasiun I, II, dan III Sungai Seketak dan mengetahui kelimpahan, keanekaragaman, serta keseragaman makrobentos di sungai Seketak. Metode yang digunakan dalam penelitian ini adalah metode survey, yaitu metode yang digunakan untuk mendapatkan informasi dari sebagian populasi yang dianggap dapat mewakili populasi tertentu. Hasil penelitian pada Stasiun I diperoleh nilai kelimpahan individu sebesar 589 ind. $/ \mathrm{m}^{2}$, indeks keanekaragaman jenis sebesar 1,14, dan indeks keseragaman sebesar 0,45; Stasiun II diperoleh nilai kelimpahan individu sebesar 273 ind. $/ \mathrm{m}^{2}$, indeks keanekaragaman jenis sebesar 0,83, dan indeks keseragaman sebesar 0,40; Stasiun III diperoleh nilai kelimpahan individu sebesar $319 \mathrm{ind} . / \mathrm{m}^{2}$, indeks keanekaragaman jenis sebesar 1,01, dan indeks keseragaman sebesar 0,57 Hasil penelitian menunjukkan bahwa kondisi perairan pada stasiun I dan III Sungai Seketak dalam kategori tercemar sedang hingga berat dan pada stasiun II dalam kategori tercemar berat.
\end{abstract}

Kata kunci: Kondisi perairan, Sungai Seketak, Makrobentos

\begin{abstract}
Seketak River is a river in the upstream region at Tembalang. The area which was previously an open area for water absorption, has changed into the campus and residential areas. As a result, community needs for facilities, especially water, increased. Therefore, blocking the Seketak river to built Diponegoro reservoirs was planned as an effort to conserve water and to control the destruction by water force. Macrobenthos group is a group of animals that are relatively settled in the bottom waters and often used as biological indicator of water quality. The research were implemented on June-July 2012. The purpose of this study were determine the waters condition of the Station I, II, and III seketak river based on macrobenthos and find out the abundance, diversity, and uniformity of macrobenthos at Seketak River. The research were determined by survey method to collect information from representated population. The results of this research on the station I obtained individuals abundance value was 589 ind. $/ \mathrm{m}^{2}$, diversity index was 1,14, and uniformity index is 0,45; Station II individual values obtained individuals abundance value was 273 ind. $/ \mathrm{m}^{2}$, diversity index was 0,83, and uniformity index was 0,40; Station III obtained individuals abundance value was 319 ind. $/ \mathrm{m}^{2}$, diversity index was 1,01, and uniformity index was 0,57. The results of this research indicated that the water condition of the Station I and III was in the medium to heavily polluted category and water condition of the Station II was in the heavily polluted category.
\end{abstract}

Key Words: Water Conditions, Seketak River, Macrobenthos

\section{Pendahuluan}

Sungai Seketak merupakan sungai yang bagian hulu berada di wilayah Tembalang, daerah yang sebelumnya merupakan daerah terbuka untuk resapan air berubah fungsi menjadi daerah kampus dan pemukiman. Sejalan dengan pertumbuhan wilayah di sekitar Sungai Seketak sebagai kompleks pendidikan dan pemukiman menyebabkan

\footnotetext{
${ }^{*}$ Penulis Penanggung Jawab
} 
meningkatnya kebutuhan masyarakat akan sarana dan prasarana, salah satunya adalah kebutuhan air. Hal tersebut menyebabkan terbentuknya perencanaan pembuatan waduk Diponegoro sebagai salah satu upaya konservasi air dan pengendalian daya rusak air yang langsung dapat dirasakan manfaatnya. Waduk Diponegoro dibangun dengan tujuan utama untuk membendung aliran sungai Seketak. Pemanfaatan waduk Diponegoro adalah sebagai waduk pendidikan yang dalam penggunaannya diharapkan waduk ini akan mampu menunjang proses pendidikan di lingkungan Universitas Diponegoro, selain itu juga memiliki manfaat bagi masyarakat di sekitar lokasi. Waduk tersebut diharapkan mampu membantu penyediaan air baku bagi masyarakat disekitar Kecamatan Tembalang dan diharapkan dapat meningkatkan pengisian air tanah serta memperbaiki kualitas air dibagian hilir Sungai Seketak.

Kelompok makrobentos merupakan kelompok hewan yang relatif menetap di dasar perairan dan sering digunakan sebagai petunjuk biologis (indikator) kualitas perairan. Bioindikator atau indikator ekologis merupakan taksa atau kelompok organisme yang sensitif dan dapat dijadikan petunjuk bahwa mereka dipengaruhi oleh tekanan lingkungan akibat dari kegiatan manusia dan destruksi sistem biotik perairan. Penelitian mengenai kondisi periaran Sungai Seketak diharapkan dapat memberikan informasi mengenai tingkat pencemaran perairan tersebut.

Tujuan dari penelitian ini adalah untuk mengetahui kondisi perairan sungai Seketak pada Stasiun I, II, dan III berdasarkan bioindikator makrobentos dan untuk mengetahui kelimpahan, keanekaragaman, dan keseragaman makrobentos di sungai Seketak. Penelitian ini dilaksanakan pada bulan Juni - Juli 2012 di sungai Seketak Semarang dan analisa laboratorium dilakukan di Laboratorium Hidrobiologi Program Studi Manajemen Sumberdaya Perairan Jurusan Perikanan Universitas Diponegoro Semarang.

\section{Materi dan Metode}

A. Hipotesis

Hipotesis ini digunakan untuk mengetahui kondisi perairan sungai Seketak Semarang berdasarkan bioindikator makrobentos. Secara sistematis menggunakan uji Friedman.

Hipotesis yang diajukan dalam penelitian ini adalah sebagai berikut:

$\mathrm{H}_{0} \quad$ : Kondisi perairan Sungai Seketak pada Stasiun I, II, dan III identik.

$\mathrm{H}_{1} \quad$ : Kondisi perairan Sungai Seketak pada Stasiun I, II, dan III tidak identik.

Dasar pengambilan keputusan:

- Jika Sig. $\geq \alpha(0,05)$, maka $\mathrm{H}_{0}$ diterima, $\mathrm{H}_{1}$ ditolak

- Jika Sig. $<\alpha(0,05)$, maka $\mathrm{H}_{0}$ ditolak, $\mathrm{H}_{1}$ diterima

B. Materi Penelitian

Materi penelitian ini adalah hewan makrobentos yang didapatkan di Sungai Seketak. Bahan yang digunakan adalah larutan formalin $4 \%$ yang digunakan untuk mengawetkan sampel yang telah didapat, dan rose bengale yang digunakan untuk membedakan antara biota sampel dengan substrat.

\section{Metode Penelitian}

\section{Metode Penelitian}

Metode yang digunakan dalam menetapkan lokasi penelitian adalah survey, yaitu metode yang digunakan untuk mendapatkan informasi dari sebagian populasi yang dianggap dapat mewakili populasi tertentu. Penetepan stasiun pengambilan sampel didasarkan atas letak inlet, tengah, dan outlet Sungai Seketak yang akan dijadikan Waduk Pendidikan Universitas Diponegoro. Pengambilan sampel dilakukan sebanyak 3 kali pada tiap stasiun.

Penentuan stasiun pengambilan sampel dilakukan setelah melakukan pengamatan langsung ke lapangan. Pengambilan sampel makrobentos dilakukan di tiga stasiun yaitu stasiun pertama berupa inlet yang terletak pada koordinat $07^{\circ} 03^{\prime} 20,1^{\prime \prime} \mathrm{S}$ an $110^{\circ} 26^{\prime} 22,2^{\prime}$ ' E, stasiun kedua berupa tengah waduk yang terletak pada koordinat $07^{\circ} 03^{\prime}$ $17,2^{\prime}$ ' S dan $110^{\circ} 26^{\prime} 31^{\prime \prime} \mathrm{E}$, dan stasiun ketiga berupa outlet yang terletak pada koordinat $07^{\circ} 03^{\prime} 10,9^{\prime}$ ' S dan $110^{\circ} 26^{\prime}$ 43,3” E. Masing-masing stasiun dilakukan pengambilan sampel sebanyak 3 kali. Skema pengambilan sampel tersaji dalam gambar 1 .

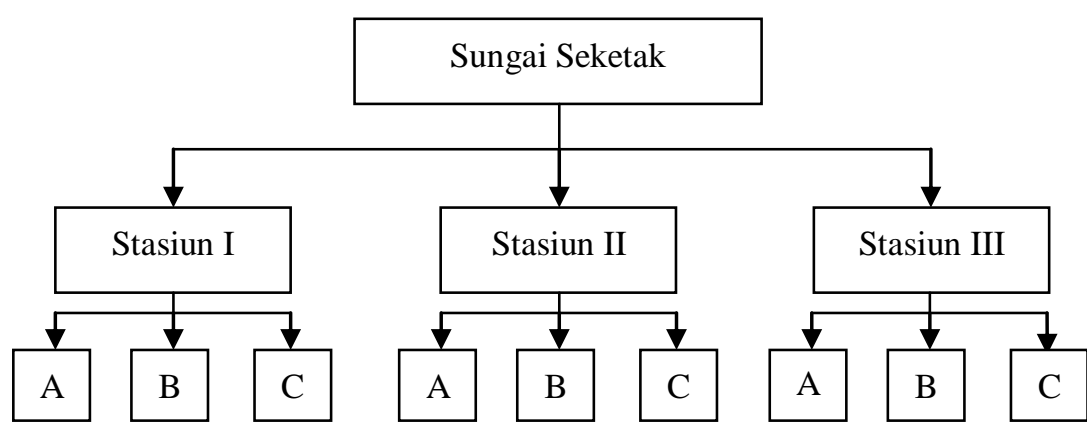

Gambar 1. Skema Pengambilan Sampel Hewan Makrobentos 
Pengambilan sampel pada setiap stasiun dilakukan dengan menggunakan bingkai kuadrat. Hal tersebut dilakukan karena substrat dasar perairan berupa batuan yang keras. Menurut Dahuri et al (1993), pengumpulan contoh bentos di sungai yang dangkal dan substrat dasar yang keras atau bebatuan digunakan Surber atau Square-foot sampler dan atau bingkai kuadrat.

Sampel kemudian disaring untuk memisahkan organisme dengan substratnya dengan menggunakan saringan berukuran $0,5 \mathrm{~mm}-1,0 \mathrm{~mm}$. Sampel yang telah didapatkan kemudian dimasukkan dalam botol sampel dan diberi larutan formalin $4 \%$ serta diberi rose bengale dan didiamkan kurang lebih 5 jam.

Sampel yang telah dipisahkan dari substrat dicuci dibawah kran air tawar, agar bau formalin dan warna merah pada air hilang, setelah itu disaring dengan saringan mesh size $1 \mathrm{~mm}$. Sampel-sampel yang telah dicuci kemudian ditempatkan di dalam cawan petri untuk dilakukan pemisahan dari kotoran. Hewan makrobentos yang telah diperoleh diidentifikasi menggunakan mikroskop binokuler dan dengan buku identifikasi Brinkhrust (1971), Thompson (2004), dan Foster (1972).

\section{Pengukuran parameter kualitas air}

a. Suhu

Memeriksa suhu air di lapangan dengan cara memasukkan termometer $\left({ }^{\circ} \mathrm{C}\right)$ ke dalam air, kemudian tunggu beberapa menit atau sampai stabil pengukurannya lalu catat nilai suhu yang tertera pada termometer.

b. Kedalaman

Mengukur kedalam perairan dengan menggunakan tongkat berskala, kemudian catat nilai dari kedalamannya.

c. Arus

Mengukur kecepatan arus dengan menggunakan bola arus yang diikat dengan tali pada permukaan perairan dan menunggu tali menegang sampai 1 meter setelah itu mengukur waktu yang dibutuhkan untuk menempuh jarak 1 meter dan mencatatnya.

Rumus:

$$
\mathrm{v}=\frac{\mathrm{s}}{\mathrm{t}}
$$

Keterangan:

$\mathrm{v}=$ Kecepatan arus $(\mathrm{m} / \mathrm{s})$

$\mathrm{s} \quad=\operatorname{Jarak}(\mathrm{m})$

$\mathrm{t} \quad=$ Waktu (s)

d. Oksigen terlarut (DO)

Mengukur kadar oksigen terlarut (DO) dengan menggunakan DO meter yang dicelupkan kedalam air hingga nilai yang tertera pada DO meter stabil, kemudian catat nilai yang didapatkan dalam pengukuran tersebut.

e. $\mathrm{pH}$

Mengambil air sampel lalu mengukur $\mathrm{pH}$ dengan kertas $\mathrm{pH}$ dan mencatat hasil pengukuran.

\section{Pengolahan data}

a. Kelimpahan atau kepadatan bentos

Menurut Dahuri et al (1993), jumlah individu per-satuan luas transek atau alat dihitung dari rata-rata jumlah individu pada beberapa pengambilan contoh dengan rumus:

keterangan:

$$
\mathrm{X}=\frac{\sum_{\mathrm{i}=1}^{\mathrm{n}} \mathrm{Xi}}{\mathrm{n}}
$$

$\mathrm{X}$ = rata-rata jumlah individu pada pengambilan contoh sebanyak $\mathrm{n}$ kali

$\mathrm{Xi}=$ jumlah individu pada pengambilan contoh ke-i

$\mathrm{n} \quad=$ jumlah pengambilan contoh

b. Kelimpahan Relatif (KR)

Kelimpahan relatif dapat dihitung dengan rumus sebagai berikut:

keterangan:

$$
\mathrm{KR}=\frac{\mathrm{ni}}{\mathrm{N}} \times 100 \%
$$

$\mathrm{KR}=$ Kelimpahan relatif

ni $\quad=$ jumlah individu

$\mathrm{N} \quad=$ jumlah total individu

c. Keanekaragam Jenis (H')

Indeks keanekaragaman jenis dihitung dengan formulasi Shannon (English et al.,1994 dalam Taqwa, 2010):

$$
\mathrm{H}^{\prime}=-\sum_{\mathrm{i}=1}^{\mathrm{s}} \text { pilnpi }
$$

keterangan:

$\mathrm{H}^{\prime}=$ Indeks keanekaragaman jenis.

$\mathrm{S}=$ jumlah spesies yang menyusun komunitas.

$\mathrm{Pi}=$ rasio antara jumlah individu spesies-i (ni) dengan jumlah individu dalam komunitas $(\mathrm{N})$. 
d. Indeks Keseragaman Jenis (e)

Indeks keseragaman dihitung dengan rumus:

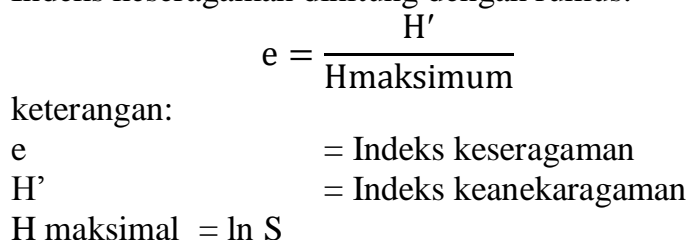

Analisa Data

Pengolahan data yang telah didapatkan menggunaka uji Friedman. Uji Friedman adalah uji nonparametrik yang digunakan untuk membandingkan tiga atau lebih kelompok data sampel yang berhubungan. Uji Friedman dimaksudkan untuk melihat apakah kelimpahan makrobentos dapat memberikan informasi mengenai kondisi perairan pada Stasiun I, II, dan III. Uji Friedman dilakukan dengan bantuan software SPSS (Daniel, 1989).

\section{Hasil dan Pembahasan}

\section{Kelimpahan individu dan kelimpahan relatif}

Berdasarkan hasil identifikasi hewan makrobentos yang didapatkan di Sungai Seketak diperoleh nilai kelimpahan individu (KI) dan nilai kelimpahan relatif (KR) yang tersaji dalam tabel 1.

Tabel 1. Kelimpahan Individu (KI) dan Kelimpahan Relatif (KR) Hewan Makrobentos yang didapatkan di Sungai Seketak

\begin{tabular}{|c|c|c|c|c|c|c|c|c|}
\hline \multirow[b]{2}{*}{ No. } & \multirow[b]{2}{*}{ Kelas } & \multirow[b]{2}{*}{ Spesies } & \multicolumn{2}{|c|}{ Stasiun I } & \multicolumn{2}{|c|}{ Stasiun II } & \multicolumn{2}{|c|}{ Stasiun III } \\
\hline & & & $\begin{array}{c}\mathrm{KI} \\
\text { (ind. } / \mathrm{m}^{2} \text { ) }\end{array}$ & $\begin{array}{l}\mathrm{KR} \\
(\%)\end{array}$ & $\begin{array}{c}\mathrm{KI} \\
\text { (ind./m²) }\end{array}$ & $\begin{array}{l}\mathrm{KR} \\
(\%)\end{array}$ & $\begin{array}{c}\mathrm{KI} \\
\text { (ind./m²) }\end{array}$ & $\begin{array}{l}\mathrm{KR} \\
(\%)\end{array}$ \\
\hline \multirow[t]{6}{*}{1.} & Oligochaeta & Ophidonais sp. & 4 & 0,68 & - & - & - & - \\
\hline & & Tubifex sp. & 66 & 11,21 & 1 & 0,37 & - & - \\
\hline & & Nais sp. & 18 & 3,06 & 1 & 0,37 & - & - \\
\hline & & Limnodrilus sp. & 8 & 1,36 & 1 & 0,37 & - & - \\
\hline & & Photamotrix sp. & 3 & 0,51 & - & - & - & - \\
\hline & & Branchiura sp. & 5 & 0,85 & - & - & - & - \\
\hline 2. & Polychaeta & Laeonereis sp. & 55 & 9,34 & - & - & - & - \\
\hline 3. & Clitellata & Glossiphonia sp. & 1 & 0,17 & 1 & 0,37 & 1 & 0,31 \\
\hline \multirow[t]{2}{*}{4.} & Hexapoda & Chironomus sp. & 408 & 69,27 & 198 & 72,53 & 36 & 11,29 \\
\hline & & Larva Hydropsyche & 1 & 0,17 & 10 & 3,66 & 179 & 56,11 \\
\hline \multirow[t]{3}{*}{5.} & Gastropoda & Ademietta sp. & 1 & 0,17 & - & - & 1 & 0,31 \\
\hline & & Melanoides sp. & 16 & 2,72 & 57 & 20,88 & 99 & 31,03 \\
\hline & & Elimia sp. & 3 & 0,51 & 4 & 1,47 & 3 & 0,94 \\
\hline
\end{tabular}

Berdasarkan hasil identifikasi hewan makrobentos yang didapatkan di Sungai Seketak diketahui pada Stasiun I diperoleh 5 kelas yaitu kelas Oligochaeta yang terdiri dari 6 genera, kelas Polychaeta yang terdiri dari 1 genus, kelas Clitellata yang terdiri dari 1 genus, kelas Hexapoda yang terdiri dari 2 genera, dan kelas Gastropoda yang terdiri dari 3 genera. Hasil identifikasi hewan makrobentos pada Stasiun II diperoleh 4 kelas yaitu kelas Oligochaeta yang terdiri dari 3 genera, kelas Clitellata yang terdiri dari 1 genus, kelas Hexapoda yang terdiri dari 2 genera, dan kelas Gastropoda yang terdiri dari 2 genera. Hasil identifikasi hewan makrobentos pada Stasiun III diperoleh 3 kelas yaitu kelas Clitellata yang terdiri dari 1 genus, kelas Hexapoda yang terdiri dari 2 genera, dan kelas Gatropoda yang terdiri dari 3 genera.

Berdasarkan hasil perhitungan kelimpahan individu pada masing-masing stasiun pengamatan diperoleh jumlah kelimpahan individu pada Stasiun I sebesar 589 ind. $/ \mathrm{m}^{2}$, pada Stasiun II sebesar 273 ind./m², dan jumlah kelimpahan individu pada Stasiun III sebesar 319 ind. $/ \mathrm{m}^{2}$. Jumlah kelimpahan individu pada Stasiun I lebih banyak daripada Stasiun II dan III. Hal tersebut terjadi karena pada Stasiun I masih terdapat substrat berupa lumpur berpasir sehingga hewan makrobentos dapat hidup. Welch (1952) dalam Wijayanti (2007) menjelaskan bahwa substrat di dasar perairan akan menentukan kelimpahan dan komposisi jenis dari hewan bentos.

Berdasarkan data jumlah hewan makrobentos yang diperoleh seperti yang tersaji pada tabel 4 diketahui bahwa pada Stasiun I dan II yang memiliki kelimpahan relatif paling tinggi adalah Chironomus sp. dengan nilai kelimpahan berturut-turut sebesar 69,27\% dan 72,53\%. Menurut Suwignyo et al (1998), Chironnomus sp. dapat hidup pada perairan sungai deras dengan kandungan oksigen terlarut yang rendah. Kelimpahan relatif paling tinggi pada Stasiun III adalah Larva Hydropysche dengan nilai kelimpahan sebesar 56,11\%. Menurut Suwignyo et al (1998) bahwa habitat Larva Hydropysche yang merupakan hewan makrobentos dari ordo Trichoptera adalah sungai dangkal dengan aliran lambat sampai deras dan kandungan oksigen terlarut tinggi, substrat batu, kerikil, pasir, lumpur, sampah atau tumbuhan air. 
Indeks Keanekaragaman (H') dan Indeks Keseragaman (e) Hewan Makrobentos

Berdasarkan hasil identifikasi hewan makrobentos yang didapatkan di Sungai Seketak diperoleh nilai Indeks Keanekaragaman (H') dan nilai Indeks Keseragaman (e) yang tersaji dalam tabel 2.

Tabel 2. Nilai Indeks Keanekaragaman (H') dan Nilai Indeks Keseragaman (e) Hewan Makrobentos yang didapatkan di Sungai Seketak

\begin{tabular}{ccc}
\hline Stasiun & $\mathrm{H}^{\prime}$ & $\mathrm{e}$ \\
\hline I & 1,14 & 0,45 \\
II & 0,83 & 0,40 \\
III & 1,01 & 0,57 \\
\hline
\end{tabular}

Berdasarkan hasil perhitungan indeks keanekaragaman jenis hewan makrobentos yang didapatkan di Sungai Seketak diperoleh indeks keanekaragaman jenis pada Stasiun I sebesar 1,14, pada Stasiun II sebesar 0,83, dan pada Stasiun III sebesar 1,01. Indeks keanekaragaman jenis pada Stasiun I dan III termasuk dalam kategori rendah, sedangkan pada Stasiun II termasuk dalam kategori sangat rendah. Menurut Lee et al (1978) dalam Soegianto (1994), bahwa klasifikasi ekologis rendah $\left(1,0 \leq \mathrm{H}^{\prime} \leq 1,59\right)$, berarti bahwa komunitas bersangkutan dalam kondisi tidak stabil dan sangat rendah $\left(\mathrm{H}^{\prime}<1,0\right)$, berarti bahwa komunitas bersangkutan dalam kondisi sangat tidak stabil. Perbedaan nilai indeks keanekaragaman jenis tersebut dipengaruhi oleh faktor fisika, yaitu arus dan kedalaman, selain itu ketersediaan makanan bagi hewan makrobentos tersebut.

Indeks keanekaragaman pada kategori rendah tersebut mungkin disebabkan oleh keberadaan individu atau spesies pada semua stasiun pengamatan relatif tidak merata. Menurut Brower et al (1990) dalam Sinaga (2009) menyatakan bahwa suatu komunitas dikatakan mempunyai keanekaragaman spesies yang tinggi apabila terdapat banyak spesies dengan jumlah individu masing-masing relatif merata. Indeks keanekaragaman jenis paling tinggi terdapat pada Stasiun I yaitu sebesar 1,14 dan indeks keanekaragaman jenis paling rendah terdapat pada Stasiun II yaitu sebesar 0,83.

Berdasarkan indeks keanekaragaman jenis dari hewan makrobentos pada masing-masing lokasi penelitian yang diamati, dapat diketahui tingkat pencemarannya. Menurut Anggoro (1988), kriteria tingkat kondisi perairan berdasarkan indeks keanekaragaman jenis tersaji dalam tabel 3.

Tabel 3. Kriteria Tingkat Kondisi Perairan Berdasarkan Bioindikator Makrobentos

\begin{tabular}{|c|c|}
\hline $\mathrm{H}^{\prime}$ & Indikasi \\
\hline$<1,0$ & $\begin{array}{ll}\text { - } & \text { Pencemaran berat } \\
\text { - } & \text { Kesuburan sulit dimanfaatkan }\end{array}$ \\
\hline $1-1,5$ & $\begin{array}{l}\text { - } \quad \text { Pencemaran sedang sampai berat } \\
\text { - } \quad \text { Kesuburan sulit dimanfaatkan }\end{array}$ \\
\hline $1,5-2$ & $\begin{array}{l}\text { - Pencemaran ringan sampai sedang } \\
\text { - Kesuburan dapat dimanfaatkan }\end{array}$ \\
\hline$>2,0$ & $\begin{array}{l}\text { - } \quad \text { Pencemaran ringan atau belum tercemar } \\
\text { - } \quad \text { Kesuburan dapat dimanfaatkan }\end{array}$ \\
\hline
\end{tabular}

Sumber: Anggoro, 1988

Berdasarkan kategori tingkat kondisi perairan berdasarkan bioindikator makrobentos dan data yang diperoleh dapat diketahui bahwa Stasiun I dan III terindikasi pencemaran sedang hingga berat dan kesuburan sulit dimanfaatkan. Stasiun II terindikasi pencemaran berat dan kesuburan sulit dimanfaatkan. Hal tersebut diduga akibat di sekitar aliran Sungai Seketak terdapat pemukiman penduduk yang membuang limbah rumah tangga ke dalam sungai sehingga memengaruhi keanekaragaman hewan makrobentos.

Keberadaan hewan dari kelas Hexapoda yaitu Chironomus sp. yang mendominasi Stasiun I dan II mengindikasi bahwa perairan tersebut telah mengalami pencemaran bahan organik. Menurut Rini (2007), Chironomus sp. merupakan organisme yang termasuk dalam golongan organisme dan merupakan indikator kunci dalam tingkat pencemaran disuatu perairan.

Hewan makrobentos yang menjadi indikator pencemaran suatu perairan selain Chironomus sp. adalah Tubifex sp., Limnodrillus sp., dan Nais sp. Hewan makrobentos dari kelas Oligochaeta tersebut merupakan biota toleran terhadap pencemaran bahan organik. Menurut Michael (1984) dalam Rosyadi et al (2009), air yang terpolusi oleh bahan organik yang cukup berat, hanya mengandung bakteri, jamur dan hewan yang tahan seperti cacing Tubifex dan larva Chironomid, selanjutnya Sastrawijaya (2000) dalam Rosyadi et al (2009), menjelaskan bahwa indikator pencemaran berat ditandai dengan adanya organisme makrobentos jenis Nais sp., Chironomus sp., dan Tubifex sp.

Keberadaan Chironomus sp. dan Tubifex sp., menandakan bahwa pemanfaatan perairan untuk kegiatan domestik oleh masyarakat di sekitar sungai termasuk kakus. Jenis Chironomus sp. dan Tubifex sp., bersifat toleran dan memiliki kemampuan osmoregulasi yang baik, sehingga organisme tersebut dapat menyesuaikan diri terhadap kondisi ekstrim yang ada di sekitarnya. 
Gastropoda yang ditemukan pada ketiga stasiun didominasi oleh jenis Melanoides sp., terutama pada Stasiun III. Menurut Musa et al (1996) dalam Zulkifli dan Setiawan (2011), makrobentos dari kelas gastropoda yaitu Melanoides sp. melimpah pada perairan yang dipengaruhi oleh limbah pertanian.

Indeks keseragaman menunjukkan adanya dominasi yang nyata. Indeks keseragaman pada Stasiun I sebesar 0,45, pada Stasiun II sebesar 0,40, dan indeks keseragaman pada Stasiun III sebesar 0,57. Berdasarakan nilai tersebut, diketahui bahwa hewan makrobentos yang didapatkan di Sungai Seketak menyebar tidak merata dan didominasi oleh jenis tertentu. Menurut Krebs (1985) dalam Sinaga (2009) menyatakan nilai indeks keseragaman mendekati 0 berarti keseragamannya rendah, karena ada jenis yang mendominasi.

\section{Parameter Kualitas Air}

Nilai parameter kualitas air yang diperoleh dalam penelitian di Sungai Seketak tersaji dalam tabel 4. Tabel 4. Nilai Rata-Rata Parameter Kualitas Air

\begin{tabular}{|c|c|c|c|c|c|}
\hline \multirow{2}{*}{ No. } & \multirow{2}{*}{ Parameter } & \multicolumn{3}{|c|}{ Stasiun } & \multirow{2}{*}{ Pustaka } \\
\hline & & I & II & III & \\
\hline 1. & Kedalaman $(\mathrm{cm})$ & 24,33 & 18,77 & 22,88 & - \\
\hline 2. & Suhu air $\left({ }^{\circ} \mathrm{C}\right)$ & 28,06 & 27,56 & 27,66 & $\begin{array}{l}20-30{ }^{\circ} \mathrm{C} \text { (Haslam, } 1985 \text { dalam Suryono et al, } \\
2009)\end{array}$ \\
\hline 3. & $\operatorname{Arus}(\mathrm{m} / \mathrm{s})$ & 2,64 & 3,05 & 3,14 & - \\
\hline 4. & $\mathrm{DO}(\mathrm{mg} / \mathrm{l})$ & 4,53 & 3,80 & 4,46 & $>6$ mg/l, (PP No. 82 Tahun 2001) \\
\hline 5. & $\mathrm{pH}$ & 7 & 7 & 7 & $7-8,5$ (Barus, 1996 dalam Sinaga, 2009) \\
\hline
\end{tabular}

Pengukuran parameter kualitas air yang dilakukan pada saat penelitian adalah pengukuran kedalaman, suhu air, arus, kandungan oksigen terlarut, dan $\mathrm{pH}$ air. Berdasarkan hasil pengukuran diperoleh nilai kedalaman pada ketiga stasiun yaitu rata-rata berkisar antara 18,77-24,33 cm. Menurut Setyobudiandi (1997) faktor kedalaman memengaruhi jumlah jenis dan jumlah individu. Stasiun I memiliki kedalaman paling dalam dari kedua stasiun lainnya yaitu sebesar $24,33 \mathrm{~cm}$ dan jumlah individu yang ditemukan pun paling banyak sebesar 589 individu. Stasiun II memiliki kedalaman paling dangkal sebesar $18,77 \mathrm{~cm}$ dan jumlah individu yang ditemukan paling rendah sebesar 273 individu.

Hasil pengukuran arus yang diperoleh dari ketiga stasiun rata-rata berkisar antara 2,64 - 3,14 m/s. Kecepatan arus tertinggi diperoleh pada Stasiun III sebesari 3,14 m/s dan terendah pada Stasiun I yaitu sebesar 2,64 m/s. Kecepatan arus tersebut memengaruhi penyebaran hewan makrobentos. Menurut Odum (1993), bahwa umumnya invertebrata bentik (bentos) mempunyai kerapatan yang paling tinggi pada air deras.

Berdasarkan hasil pengukuran suhu air pada ketiga stasiun diperoleh rata-rata nilai berkisar antara $27,56-28,06^{\circ} \mathrm{C}$. Menurut Sukarno (1981) dalam Wijayanti (2007) bahwa suhu dapat membatasi sebaran hewan makrobentos secara geografik dan suhu yang baik untuk pertumbuhan hewan makrobentos berkisar antara $25-31^{\circ} \mathrm{C}$. Nilai suhu yang diperoleh pada Stasiun I sebesar $28,06^{\circ} \mathrm{C}$, pada Stasiun II sebesar $27,56^{\circ} \mathrm{C}$, dan pada Stasiun III sebesar $27,66^{\circ} \mathrm{C}$. Suhu air pada ketiga stasiun tersebut relatif sama, hal tersebut disebabkan oleh keadaan cuaca yang relatif sama.

Rata-rata nilai kandungan oksigen terlarut (DO) pada Stasiun I sebesar 4,53 mg/l, pada Stasiun II sebesar 3,80 $\mathrm{mg} / \mathrm{l}$, dan pada Stasiun III sebesar $4,46 \mathrm{mg} / \mathrm{l}$. Hal tersebut menunjukkan bahwa nilai kandungan oksigen terlarut di Sungai Seketak rendah sehingga banyak ditemukan Chironomus sp., terutama pada Stasiun I dan II. Menurut PP No. 82 Tahun 2001, nilai optimum oksigen terlarut adalah lebih dari 6 mg/l, selanjutnya Sastrawijaya (2000) dalam Rosyadi (2009), menjelaskan bahwa hewan makrobentos dari spesies Tubifex sp. dan Malanoides sp. merupakan spesies indikator adanya oksigen terlarut (DO) rendah pada ekosistem perairan sungai. Berdasarkan PP No. 82 Tahun 2001 tentang Pengelolaan Kualitas Air dan Pengendalian Pencemaran Air, kadar DO pada stasiun I dan III tersebut termasuk dalam kategori kelas II, yaitu digunakan untuk prasarana atau sarana rekreasi air, pembudidayaan ikan air tawar, peternakan, air untuk mengairi pertanaman, dan atau peruntukan lain yang memiliki syarat mutu air yang sama dengan kegunaan tersebut dan pada Stasiun II termasuk dalam kelas III yaitu digunakan untuk pembudidayaan ikan air tawar, peternakan, air untuk mengairi pertanaman, dan atau peruntukan lain yang memiliki syarat mutu air yang sama dengan kegunaan tersebut.

Nilai $\mathrm{pH}$ menunjukkan derajat keasaman atau keadaan kebasaan suatu perairan. Nilai $\mathrm{pH}$ yang diperoleh dari ketiga stasiun pengamatan adalah sebesar 7. Nilai pH 7 menunjukkan kondisi perairan tersebut masih dapat mendukung kehidupan dan perkembangan hewan makrobentos. Menurut Barus (1996) dalam Sinaga (2009) menyatakan bahwa Nilai pH yang ideal bagi kehidupan organisme akuatik pada umumnya terdapat antara $7-8,5$.

\section{Analisa Data}

Pengujian kondisi perairan Sungai Seketak dengan menggunakan uji Friedman. Langkah pertama dalam uji Friedman adalah membuat peringkat nilai-nilai kelimpahan individu dari masing-masing stasiun penelitian dari yang terkecil hingga yang terbesar. Langkah kedua dalam menghitung statistik uji ini adalah mendapatkan jumlah peringkat dari masing-masing stasiun, jika $\mathrm{H}_{0}$ diterima, maka jumlah peringkat tersebut cukup identik sampai identik. Menurut Daniel (1989), uji Friedman merupakan prosedur yang menggunakan data dari tiga sampel berhubungan atau lebih. Perhitungan dalam uji Friedman menggunakan peringkat yang diurutkan dari hasil pengamatan yang diukur dengan skala yang tinggi. 
Berdasarkan hasil perhitungan dengan uji Friedman diketahui bahwa $\mathrm{H}_{0}$ diterima karena nilai asymp. Sig atau asymptotic significance adalah 0,428 , atau probabilitas diatas $0,05(0,428 \geq 0,05)$ sehingga dapat diperoleh kesimpulan bahwa kondisi perairan Sungai Seketak pada Stasiun I, II, dan III identik.

Kondisi perairan Sungai Seketak pada Stasiun I, II, dan III yang identik tersebut sama dengan kategori berdasarkan indeks keanekaragaman yaitu tercemar sedang hingga berat. Kondisi perairan tersebut ditandai dengan didapatkannya jenis hewan makrobentos yang toleran terhadap pencemaran perairan seperti Chironomus sp., Tubifex sp., Limnodrillus sp., dan Nais sp. Jenis Melanoides sp. yang didapatkan juga menunjukkan bahwa perairan tersebut memiliki kadar oksigen yang rendah.

\section{Kesimpulan}

Berdasarkan hasil penelitian yang telah dilakukan, maka dapat diambil kesimpulan sebagai berikut:

a. Berdasarkan kriteria tingkat kondisi perairan, Sungai Seketak pada Stasiun I dan III dalam kategori tercemar sedang hingga berat dan kondisi perairan, Sungai Seketak pada Stasiun II dalam kategori tercemar berat;

b. Hasil penelitian pada Stasiun I diperoleh nilai kelimpahan individu sebesar $589 \mathrm{ind} . / \mathrm{m}^{2}$, indeks keanekaragaman jenis sebesar 1,14, dan indeks keseragaman sebesar 0,45. Hasil perhitungan pada Stasiun II diperoleh nilai kelimpahan individu sebesar 273 ind. $/ \mathrm{m}^{2}$, indeks keanekaragaman jenis sebesar 0,83 , dan indeks keseragaman sebesar 0,40. Hasil perhitungan pada Stasiun III diperoleh nilai kelimpahan individu sebesar 319 ind./m² , indeks keanekaragaman jenis sebesar 1,01, dan indeks keseragaman sebesar 0,57.

\section{Daftar Pustaka}

Anggoro, S. 1988. Analisis Tropik-Saprobik (Trosap) Untuk Menilai Kelayakan Lokasi Budidaya Laut. Dalam: Workshop Budidaya Laut Universitas Diponegoro. Jepara.

Brinkhurst, R. O. 1971. A Guide for The Identification of British Aquatic Oligochaeta. University of Toronto. Canada.

Dahuri, R., Putra, I. N. S., Zairon, dan Sulistiono. 1993. Metode dan Teknik Analisis Biota Perairan. Pusat Penelitian Lingkungan Hidup. Institut Pertanian Bogor. Bogor.

Daniel, W. W. 1989. Statistika Nonparametrik Terapan. Gramedia. Jakarta.

Foster, N. 1972. Freshwater Polychaetes (Annelida) of North America. Dunbarton Collage. Washington D. C.

Odum, E.P. 1993. Dasar-dasar Ekologi (Translated from English by Samingan T and Srigandono). Gajah Mada Press. Yogyakarta.

Peraturan Pemerintah No. 82 Tahun 2001

Rini, D. A. 2007. Mengenal Makroinvertebrata Bentos. Warta Konversi Lahan Basah. http://www.onrizal.files.com (02 Juni 2012).

Rosyadi, S. Nasution, dan Thamrin. 2009. Distribusi dan Kelimpahan Makrozoobenthos di Sungai Singingi Riau. J. Environmental Science, 3(1):58-74.

Setyobudiandi, I. 1997. Makrozoobentos. Institut Pertanian Bogor. Bogor.

Sinaga, T. 2009. Keanekaragaman Makrozoobentos Sebagai Indikator Kualitas Perairan Danau Toba Balige di Kabupaten Toba Samosir. [Tesis]. Sekolah Pascasarjana, Universitas Sumatra Utara, Medan, 93 hlm.

Soegianto, A. 1994. Ekologi Kwantitatif Metode Analisis Populasi Komunitas. Usaha Nasional. Surabaya.

Suwignyo, S., B. Widigdo, Y. Wardiatmo, dan M. Krisanti. 1998. Avertebrata Air Untuk Mahasiswa Perikanan. Institut Pertanian Bogor. Bogor.

Taqwa, A. 2010. Analisis Produktivitas Primer Fitoplankton Dan Struktur Komunitas Fauna Makrobenthos Berdasarkan Kerapatan Mangrove di Kawasan Konservasi Mangrove dan Bekantan Kota Tarakan, Kalimantan Timur. [Tesis]. Program Pascasarjana, Universitas Diponegoro, Semarang, $109 \mathrm{hlm}$.

Thompson, F. G. 2004. An Identification Manual for The Freshwater Snails of Florida. http://www.filmnh.ufl.edu/natsci/malacology/fl-snails/snails.htm (24 Juni 2012).

Wijayanti, H. 2007. Kajian Kualitas Perairan di Pantai Bandar Lampung Berdasarkan Komunitas Hewan Makrobenthos. [Tesis]. Program Magister Manajemen Sumberdaya Pantai, Universitas Diponegoro, Semarang, $89 \mathrm{hlm}$. 